\title{
Floyd Merrell named sixth Thomas A. Sebeok Fellow of the Semiotic Society of America
}

\section{John Deely ${ }^{1}$}

The combined 29th \& 30th Annual Meeting of the Semiotic Society of America was held on the campus of the University of West Florida in Pensacola on October 20-22. At this meeting, Professor Floyd Merrell of Indiana University/Purdue University (IUPUI) was inscribed as the sixth Thomas A. Sebeok Fellow. Professor Merrell's Fellow Address, forthcoming in The American Journal of Semiotics, entitled "The Magical Number Three", addressed the nature of the Peircean sign in light of a nonlinear, complemented, context-dependent lattice, with particular focus on how the lattice: (1) reveals the function of distinctions between signs; (2) supports Peirce's triadic notion of semiosis; (3) models the notion of signs incessantly becoming other signs; (4) takes its leave of classical logical principles; and (5) accounts for the emergence of novelty - spontaneous, fresh, unique signs.

There are few names better known in the semiotic circles of North America than that of Floyd Merrell. While all of Floyd's writings involve semiotics, he considers the following from among his books to be "central to semiotics": Semiotic Foundations: Steps Toward an Epistemology of Written Texts (1982; selected by Choice as an outstanding academic book of the year); A Semiotic Theory of Texts (1985); On Semiotic Modeling, edited with Myrdene Anderson (1991); Signs Becoming Signs: Our Perfusive, Pervasive Universe (1991); Sign, Textuality, World (1992); Semiosis in the Postmodern Age (1995a); Peirce's Semiotics Now: A Primer (1995b); Signs Grow: Semiosis and Life Processes (1996); Peirce, Signs, and Meaning (1997); Sensing Semiosis: Toward the Possibility of Complementary Cultural "Logics" (1998a); Introducción a la semiótica de C. S. Peirce (1998b); Tasking Textuality (2000a); Change, Through Signs of Body, Mind, and Language (2000b); Signs, Science, Self-Subsuming (Arti)Facts (2000c); Signs for Everybody: Or, Communication, Quandaries, and Chaos (2000d); Living

1 Author's address: John Deely, University of St. Thomas, 3800 Montrose Blvd., Houston, TX 77006, USA; e-mail: deelyj@stthom.edu. 
Learning, Learning Living: Signs, East and West (2002); Sensing Corporeally: Toward a Posthuman Understanding (2003).

\section{Background to the Sebeok Fellow Award}

The Sebeok Fellow Award is the highest honor given by the Semiotic Society of America. The idea for this award was introduced in 1991 by the thenExecutive Director, Dean MacCannell, and approved by the Executive Board. An Awards and Recognition committee was established to choose a first recipient. As the Society's official newsletter, the Semiotic Scene 4.1 (1993), put it: "The Sebeok Fellowship is awarded to honor substantial career or lifetime contributions to semiotics and service to the semiotic community. The committee is not required to select a Fellow each year." The practice has been to nominate a Sebeok Fellow only on such occasions as a strong consensus plainly emerges around a proposed name.

The title for the award was chosen in honor of Dr. Thomas Albert Sebeok (9 November 1920-2001 December 21), founder of the SSA, and himself a pioneer both nationally and globally in the establishment of semiotics as a doctrine of signs respecting which the development of "semiology", as a kind of 'social science' in the modern sense of language and culture, could be seen as no more than a part of the larger process of anthroposemiosis which itself, in turn, is no more than a part of the still larger semiosis of the world of nature itself and as a whole.

\section{The list of Sebeok Fellows}

The choice of Sebeok Fellows had a lugubrious beginning. A dramatic turn of events within the Society, namely, the unexpected death of its Vice-President/President-elect, Dr. David Savan (1916-1992), in the late Spring of 1992, led the committee to make the first award a post-mortem honor. Thus the first Thomas A. Sebeok Fellow was chosen to be the late Dr. David Savan, a senior scholar of considerable distinction ${ }^{2}$ and one of the pioneers of semiotics in North America. Among his contributions, particular mention can be made of his An Introduction to C. S. Peirce's Full System of Semeiotic (1988).

2 Cf. http://www.pragmatism.org/genealogy/savan.htm. 
The complete list of Sebeok Fellows is as follows:

1. David Savan (1916-1992; posthumously awarded 1992);

2. John Deely (1993; St Louis Meeting);

Sebeok Fellow Address, 22 October 1993: "How Does Semiosis Effect

Renvoi?" (Deely 1994);

3. Paul Bouissac (1996; Santa Barbara Meeting);

Sebeok Fellow Address, 19 October 1996: "Can Semiotics Progress?" (Bouissac 2000);

4. Jesper Hoffmeyer (2000; Purdue Meeting);

Sebeok Fellow Address, 29 September 2000: "The Central Dogma: A Joke that Became Real" (Hoffmeyer 2002);

5. Kalevi Kull (2003; Ottawa Meeting);

Sebeok Fellow Address, 10 October 2003: "Semiotics Is a Theory of Life" (Kull 2005);

6. Floyd Merrell (2005; Pensacola Meeting);

Sebeok Fellow Address, 22 October 2005: "Chewing Gum, Ambulating, and Signing, all at the Same Time: Or, The Magical Number Three", forthcoming in The American Journal of Semiotics.

7. To be named.

\section{References}

Anderson, Myrdene; Merrell, Floyd (eds.) 1991. On Semiotic Modeling. (Approaches to Semiotics 97.) Berlin: Mouton de Gruyter.

Bouissac, Paul 2000. Can semiotics progress? The American Journal of Semiotics 15/16: 7-26.

Deely, John 1994. How does semiosis effect renvoi? The American Journal of Semiotics 11(1/2): 11-61.

Hoffmeyer, Jesper 2002. The Central Dogma: A joke that became real. Semiotica 138(1/4): 1-13.

Kull, Kalevi 2005. Semiotics is a theory of life. In: Williamson, Rodney; Sbrocchi, Leonard G.; Deely, John (eds.), Semiotics 2003. Ottawa: Legas, 1531.

Merrell, Floyd 1982. Semiotic Foundations: Steps Toward an Epistemology of Written Texts. Bloomington: Indiana University Press.

- 1985. A Semiotic Theory of Texts. Berlin: Mouton de Gruyter.

- 1991. Signs Becoming Signs: Our Perfusive, Pervasive Universe. Bloomington: Indiana University Press.

- 1992. Sign, Textuality, World. Bloomington: Indiana University Press. 
- 1995a. Semiosis in the Postmodern Age. West Lafayette: Purdue University Press.

- 1995b. Peirce's Semiotics Now: A Primer. Toronto: Canadian Scholars' Press.

- 1996. Signs Grow: Semiosis and Life Processes. Toronto: University of Toronto Press.

- 1997. Peirce, Signs, and Meaning. Toronto: University of Toronto Press.

- 1998a. Sensing Semiosis: Toward the Possibility of Complementary Cultural "Logics". New York: St. Martin's Press.

- 1998b. Introducción a la semiótica de C. S. Peirce. Maracaibo: Ediciones Astro Data.

- 2000a. Tasking Textuality. Hamburg: Peter Lang.

- 2000b. Change, Through Signs of Body, Mind, and Language. Chicago: Waveland Press.

- 2000c. Signs, Science, Self-Subsuming (Arti)Facts. Dresden: Thelem Press.

- 2000d. Signs for Everybody: Or, Communication, Quandaries, and Chaos. Ottawa: Legas Press.

- 2002. Living Learning, Learning Living: Signs, East and West. Ottawa: Legas Press.

- 2003. Sensing Corporeally: Toward a Posthuman Understanding. Toronto: University of Toronto Press.

Savan, David 1988. An Introduction to C. S. Peirce's Full System of Semeiotic. (Toronto Semiotic Circle Monographs No. 1.) Toronto: Toronto Semiotic Circle. 